24 Roslyn L. Knutson, Playing Companies and Commerce in Shakespeare's Time (Cambridge, 2001), 57-9.

25 Ibid, 59-61.

26 'Godfrey of Bouillon', Encyclopaedia Britannica, 2009.

27 Richard Lloyd, A Brief discourse of ... The Nine Worthies (London, 1584), sig. G1v.

28 See Mark Thornton Burnett, 'Marlovian Imitation and Interpretation in Heywood's The Four Prentices of London', Cahiers Élisabéthains 32 (1987), 75-8.

29 Thomas Heywood, The Four Prentices of London: A Critical, Old-Spelling Edition, ed. Mary Gaisor (New York, 1980), 11. 2261-7. All further quotations from the play will be taken from this edition and reference will be given in the text.

30 Algernon Charles Swinburne, Age of Shakespeare (London, 1908), 222-3.

31 Arthur Melville Clark, Thomas Heywood: Playwright and Miscellenist (Oxford, 1931), 210.

32 Frederick S. Boas, Thomas Heywood (New York, 1975), 26.

33 Matar, Turks, Moors, and Englishmen, 142-3.

34 G.K. Hunter, 'The Emergence of the University Wits: Early Tragedy', in English Drama 1586-1642: The Age of Shakespeare (Oxford, 1997), 49.

\title{
'Now will I be a Turke': Performing Ottoman Identity in Thomas Goffe's The Courageous Turk
}

In the past several years, scholars have devoted increasing attention to representations of the Near East and of Persian, Moorish, or Turkish characters in early modern English drama. Many of these studies have examined the cultural, political, and economic encounters between the English and Islamic or quasi-Islamic others, and the ways in which early modern English writers constituted their own identity through representations of the other. In particular, critics such as Daniel Vitkus have focused on the permeability of the boundaries between the ideological constructs of East and West, and the hybrid identity assumed by Englishmen who ventured into what he calls the 'multicultural Mediterranean'. Thus, English identity was constituted not only in antithetical contrast to Near Eastern cultures, but also by the possibility of assimilation into those cultures — of 'turning Turk'.

But what happens when playwrights attempt to reverse this perspective, when the world of the play itself — its setting and most of its characters — turns Turk? Several early modern English plays center around Turkish 
characters and settings, so that these characters occupy the position of the subject and not the position of the other. Placing the cardboard villains of Renaissance drama in the position of the protagonists forces the playwright to develop their complexity and make them more sympathetic. If the play is almost entirely populated by Turks, they cannot all be the same, and they cannot all spout moral nonsense; they must have debates, and the debates must have some merit on either or both sides.

Playwrights, I argue, use this shift of perspective to dramatize a sense of radical indeterminacy, not just about English or Turkish national identity but about human identity more broadly. For this purpose, they exploit both the cultural alterity and the stereotypical conventionality of the stage Turk and related figures such as the Moor. In general, these figures tend to share certain stereotypical qualities: they are prone to outbursts of both violent and erotic passion, their passions are changeable and difficult to control, and they are capable of extreme cruelty. In Shakespeare's Titus Andronicus, for example, Aaron the Moor embodies the most negative versions of this stereotype. Apart from his devotion to his illegitimate child, Aaron is extravagantly evil. He concludes the play by repenting any good deeds he may have inadvertently performed and wishing that he could have committed ten thousand more evil deeds (5.3.185-90). ${ }^{1}$ While Aaron's adherence to Moorish stereotypes makes him fascinating as a demonic embodiment of evil, it makes him less interesting as a human being. As we would expect, his stereotypical characteristics reduce our sense of him as a three-dimensional personality with a psychological interiority that resembles our own experiences of ourselves and other people.

Later in his career, however, Shakespeare uses Moorish stereotypes to produce the opposite effect. In Othello, the title character's psychological depth becomes apparent through his increasing conformity to the stock character of the Moor. Under the influence of Iago and his own insecurities, he grows jealous, vengeful, and cruel; he comes to be ruled by his passions. Othello begins in a state where he transcends the racist expectations of characters such as Brabantio, but he ends by fulfilling them. Othello's closing speech recognizes this: as he recounts his former slaying of 'a malignant and a turbaned Turk' (5.2.353), Othello stabs himself and draws an analogy between the two killings. He thereby identifies himself with Elizabethan archetypes of the villainous Moor or Turk. Yet the process of Othello's degeneration into a stereotype is precisely what produces a sense of his humanity and inner complexity. Iago 
corrupts Othello only because Othello has subconscious psychological vulnerabilities that stem from his identity as a Moor.

Shakespeare is not unique in this respect. Several other playwrights use these kinds of stereotypes (which should reduce ambiguity and oversimplify the subject) to increase the unpredictability and ambiguity of their characters' actions and the complexity of their plays' commentary. In this paper, I examine the ways in which Thomas Goffe's The Courageous Turk deploys Turkish stereotypes to produce a more ambivalent and nuanced exploration of the relationships between passion and restraint, and between Turks and Christians.

The Courageous Turk has received relatively little attention from modern critics, who have tended to assume that it lacks interpretive interest. Matthew Dimmock notes that

plays like Thomas Goffe's The Raging Turke (1613-1618?) and The Couragious Turke (1618), probably based directly on Knolles [Richard Knolles's The Generall Historie of the Turkes (1603)], reflect closely the ideological investments of the latter's chronicle history. Goffe's bombastic dramatization of Ottoman dynastic disputes imitates the structure of Tamburlaine and Selimus, yet replaces the ambiguities of these earlier plays with a one-dimensional Ottoman stereotype - the 'subverter and sworn enemie of the Christians, and of all that call upon Christ'. ${ }^{2}$

The word 'bombastic' appears in virtually every commentary on Goffe's play, and the play's hyperbolic style, derived ultimately from Tamburlaine, does not at first glance suggest a nuanced approach to its subject matter. I would like to suggest, however, that the play's dramatization of Ottoman stereotypes actually develops interpretive complexities present in Knolles's Generall Historie.

The Courageous Turk was first published posthumously in 1632 as The couragious Turke, or, Amurath the First. Its plot does derive from Knolles, but Goffe stitches together the histories of two different rulers and attributes the actions of both to his protagonist Amurath: acts 1-2 come from Knolles's account of Mahomet II (Mehmed II, 1432-1481), and acts 3-5 dramatize episodes from the life and death of Amurath I (Murad I, 1319-1389). ${ }^{3}$ Goffe also includes significant verbal and situational echoes of Shakespeare's Othello (such as Othello's temptation by Iago and Othello's murderous contemplation of the sleeping Desdemona) and Hamlet (Amurath receives analogues of the ghost's appearance to Hamlet and the play staged for Claudius). 
In Goffe's play, Amurath, king of the Turks, falls in love with a Greek captive, Eumorphe (called Irene in Knolles). His tutor Lala Schahin, feeling that Amurath is neglecting his kingly responsibilities because of his love for Eumorphe, stages two masques and fakes a ghostly visitation in order to convince Amurath to 'cut this Gordian thred, and rend hence, / That putrid Wenne which cleaves unto thy flesh' (2.4.38-9). ${ }^{4}$ The chastened Amurath publicly beheads Eumorphe and embarks on a program of military conquest. Meanwhile, we are introduced to the Christians and one of their captains, the pious Cobelitz (Miloš Obilić), who tries to overcome the fear and infighting that plague the Christian forces. After winning victories against the Christians, Amurath attacks and defeats his son-in-law Aladin. Amurath threatens to kill Aladin's children but then relents and makes peace with Aladin. They proceed to 'Cassanoe's Plaines' in 'Servia' (5.1.136-8) to defeat the Christian army there (the 1389 Battle of Kosovo). Amurath receives a visitation from his demonic ancestors, who warn him of his impending doom, but he ignores the warning. The Turks defeat the Christians in battle, and Cobelitz is apparently killed. However, when Amurath approaches to view his victory, Cobelitz rises and manages to fatally stab Amurath with a dagger before dying himself. Amurath's son Baiazet offers to share the monarchy with his brother Jacup, but Schahin and others remind him that 'the Turkish Lawes' require Jacup's death (5.4.143). Jacup upbraids Baiazet and allows himself to be strangled, wrapping his own scarf about his neck and offering the other end to Baiazet.

The most shocking event of the play, Amurath's sudden decision to behead the woman he loves, evidently captured the imagination of early modern writers and audiences, for it received multiple treatments during the period. Besides being told by Knolles, the episode was presumably recounted in a now lost play by George Peele, The Turkish Mahomet and Hiren the Fair Greek, produced around 1594 and famously alluded to in 2 Henry $I V$ (2.4.154). It was also the subject of a 1611 poem by William Barksted entitled Hiren: or The faire Greeke. After Goffe, the subject received other dramatic treatments, including Lodowick Carlell's Osmond The Great Turk, Or The Noble Servant, published in 1657.

By combining the love of Mahomet II with the military conquests of Amurath I (and the murderous dynastic succession following his death), a fusion not found in other sources or analogues, Goffe constructs a protagonist whose potential for social action is defined by the opposing demands of love and war, and both love and war become debased as Amurath navigates 
his way through their conflicting imperatives. In these respects, the play owes less to self-congratulatory anti-Ottoman propaganda and more to the cynical philosophical disillusionment of Shakespeare's Troilus and Cressida.

The conflict between love and war, a trope derived from the romance and epic traditions and common in early modern drama, is significantly inflected by placing it in an Ottoman context. In particular, Goffe plays with the stereotype of the Turks as slaves to their amatory and homicidal passions and thereby expands on an issue already present in Knolles's Generall Historie. Knolles describes Mahomet II's dalliance with Irene as the product of 'disordered affections, where reason ruleth not the reine', a vice typical of the bombastic stage Turk. Mahomet II appears to rise above this stereotype, presenting his slaying of Irene as a supreme example of Stoic temperance and his ability to 'bridle' his affections. However, Knolles comments that he embarks on his subsequent military campaigns 'to discharge the rest of his choller', suggesting that excess of passion, rather than the proper restraint of passion, prompted the beheading of Irene. ${ }^{5}$ Goffe's dramatization of Knolles calls into further question the relationship between the twin antitheses of love/war and passion/restraint, as well as which of these four elements is more distinctively Turkish.

Goffe's Amurath seems to be motivated by his stereotypically Turkish passions as both a lover and a fighter. As the play opens, Amurath hyperbolically declares his complete abandonment to the passion of lust: 'Jove Ile outbrave thee! melt thy selfe in Lust ... Ile not envie thee' (1.1.25-7). When Amurath turns to military conquest, he displays equally intense passion. Schahin offers Amurath the severed heads of Christians 'to adde freshe oyle unto thy hate, / And make it raise it selfe a greater flame' (3.2.13-14), and Amurath responds, with gusto, 'O how it glads me thus to pash their braines, / To rend their lockes, to teare these Infidels!' (3.2.23-4). He repeatedly expresses a desire to drink Christian blood (3.2.44, 4.2.89).

Both kinds of passion, however, draw condemnation from other characters — including Turkish ones — which calls into question the idea of a monolithic Turkish viewpoint. Eumorphe worries that Amurath's amorous feelings resemble 'streames ... Which with outragious swelling flow to fast' (1.1.334). Schahin laments that Amurath lies 'Drencht in the Lethe of Ignoble lust' (1.2.21). Amurath himself recognizes that his passion for Eumorphe may lead his countrymen to 'Call me a Lusty, Lazy, wanton, Coward!' (2.3.56). The Turkish characters present Amurath's indulgence in love as lazy and bestial, a failure to restrain the passions, a disease — a position more congruent with 
Christian moralism than with stereotypes of the stage Turk, and one the play might be genuinely advocating to its audience. Amurath's sadistic violence receives condemnation mostly from Cobelitz and the Christian forces. But Goffe also includes a scene where Amurath threatens to kill his own grandchildren in retaliation for his son-in-law Aladin's rebellion, and Amurath's daughter begs him to restrain his fury.

The play's representation of Turkish passions is thus complicated by the discourse of Stoic temperance and restraint, which pervades the play and produces contradictory narratives about the moral significance of Amurath's movement from lover to warrior via the slaying of Eumorphe. Because Goffe's audience presumably opposed the military expansion of the Ottoman Empire into Europe, and because Goffe's play contains significant echoes of Shakespeare's Othello, we might expect The Courageous Turk to be the tragedy of how Amurath's trusted advisor Schahin wickedly deceives him into a murderous rage, causing him to kill his true love and embark upon an ultimately selfdestructive campaign of military conquest. And in fact, the play does provide some support for this view of a virtuous Stoic love shattered by intemperate violence. Eumorphe seems to be an honourable woman who tries to bring out the best in Amurath. She identifies beauty as 'the worst part of woman' (1.3.8) and argues for a relationship based on 'obedience, duty, carefull Love' (21). In response, Amurath vows to worship 'That vertue in thy brest' (36). Eumorphe's description presents proper love as a kind of restraint. The play begins with Amurath silencing the 'harsh notes' of the martial music to which he has entered because his 'softer eares' have turned to love (1.1.1). He thus frames love in terms of refraining from violence, which he characterizes as a kind of servitude. Amurath says that 'we / Scorne to be made the servile Ministers' of the Fates 'To cut those threads' of people's lives (1.1.9-11).

Amurath's love also transforms his political attitudes, causing him to reject the moral authority of kingship:

Turke, Amurath, slave nay something baser,

King! For all aery titles which the Gods

Have blasted man withall, to make them swell

With puft up honour, and ambitious wind,

This name of King holds greatest antipathy

With manly government. 
Amurath invokes the Stoic virtue of masculine self-government and suggests that it is antithetical to oriental despotism and military conquest. When Amurath begins to waver in this resolve as he contemplates, Othello-like, the sleeping Eumorphe, the intemperance and hubris of his expression of ambition seem to demonstrate the truth of his earlier statement:

Hence, then thambition of that furious youth,

Who knew not what a crime his rashnesse was!

I might orecome more Kingdomes; have more dominion

Enthrone my selfe an Emperor! oth' world,

I might! I might! Amurath thou mightst!

He describes war as furious ambition and then becomes a furious megalomaniac as he succumbs to that ambition. In this view of the play, then, Schahin serves as an Iago figure who unleashes Amurath's violent passions, resulting in the horrifying spectacle of Eumorphe's beheading and Amurath's impious and doomed attempt to conquer the world. Vitkus argues for this interpretation of the play: 'The irony is that Amurath, like Othello, has been "wrought" upon by a male follower who succeeds in turning him against the virtuous woman he loves and in bringing on his death and damnation. In both cases, dramatic irony exposes the murderer's misogynist code as damnable and deadly to himself'. 6

The play, however, also incorporates a powerful contrary narrative, in which Amurath's love represents a lack of self-control and Schahin recalls him to his neglected duties and responsibilities as a ruler. Schahin differs in important ways from evil counsellors such as Iago. From his first soliloquy in 1.2, Schahin consistently claims to act for the good of both Amurath and his empire - and this corresponds to his portrayal in Knolles, who praises his 'graue aduice and counsaile. ${ }^{7}$ Schahin's political advice in the play is generally sensible; for example, he encourages a productive alliance between Amurath and the Anatolian ruler 'The German Ogly' (3.5.19). To Schahin, Amurath's love for Eumorphe is 'intemperate Lust' (2.4.4) and therefore she represents a 'putrid Wenne' (2.4.39) on Amurath that Schahin intends to cure by instilling in Amurath Stoic self-discipline. Schahin presents himself as a voice of temperance, advocating that Reason, 'that best part of man', should

sway and rule each Passion.

Affections are good Servants: but if will 
Make them once Master, theyle prove Tyrants still. $\quad(1.2 .10-13)^{8}$

Although Schahin's judgment of Eumorphe is misogynist, and his manipulation inspires misogyny in Amurath, Eumorphe herself agrees with the principle that 'those are Kings, and Queenes whose brest's secure / Like brazen walles, Lust's entrance not endure!' (2.2.30-1). Seen from this perspective, Amurath's beheading of Eumorphe is a supreme example of temperate behaviour and 'manly government' (2.3.6). Amurath explicitly challenges his court to be 'temperate' enough to resist the temptation of Eumorphe's beauty (2.5.34) and he justifies the beheading with the quasi-Stoic maxim that 'he surely shall / That conquers first himselfe, soone conquer all' (2.5.84-5).

Compared to its sources and analogues, the decapitation scene in The Courageous Turk systematically de-emphasizes the notorious emotionality of the Turks and highlights the issue of self-control. In Knolles, the Sultan Mahomet presents Irene to his court, who had been displeased with his dalliance, and 'they all rapt with an incredible admiration to see so faire a thing, the like whereof they had neuer before beheld, said all with one consent, That he had with greater reason so passed the time with her, than any man had to find fault therewith'. Being 'altogither ignorant of the Sultans mind', they are struck with 'great terror' when Mahomet kills Irene, thereby enacting an extreme form of their advice immediately after forcing them to recant it. ${ }^{9}$ In Goffe's version of this scene, the key members of Amurath's court are all in on Schahin's plot to turn Amurath against Eumorphe. As a result, when they view her beauty and declare that they would not be able to resist her charms, their claims are not an instance of how readily Turks may be swayed by amatory passions but rather an instance of Machiavellian political theatre.

In Barksted's poem, as in all of the versions, Mahomet does link his decision to kill Hiren to Stoic values and a desire to demonstrate 'That I can rule my owne affection'. The Stoic façade of Barksted's Mahomet, however, dissolves into a kaleidoscope of unbridled passions as soon as he kills Hiren. He immediately regrets his actions, slays Mustapha (the honourable soldier who warns him that he has been neglecting his responsibilities), calling him a 'diuell', laments Hiren's death, briefly contemplates suicide, and finally out of bitterness devotes himself to 'bloudy warre'. ${ }^{10}$ In Goffe, Amurath maintains his composure, offers a moralistic speech about the foolishness of doting on female beauty, speaks in a friendly way to Schahin, the advisor who convinced him to kill Eumorphe, and seems cheerful about moving on to a campaign of military conquest (2.5.73-82). 
As Goffe's play shifts to the military conquests of Knolles's Amurath I, it demonstrates the savagery with which Amurath wages war, but the play also describes such conquests as admirable examples of fortitude and 'noble deeds' (1.5.91). Even the Christian hero Cobelitz shares the ethic of self-denial and militarism. When the Serbian governor Lazarus suggests that there is no point in fighting the superior Turkish army, Cobelitz replies that 'Ease and successe keeps basenesse company' (3.3.16), valorizing suicidal combat over rational military calculations. Through cowardice and infighting, Lazarus and most of the other Christian forces fail to live up to Cobelitz's principles. The Christians appear particularly contemptible in 3.3, where a drunken argument between soldiers degenerates into a catfight between their 'Laundresses', identified in the stage directions as 'Truls' (3.3.45, $46 \mathrm{sd}$ ).

In presenting Amurath's conquests as simultaneously terrifying and enviable, Goffe reflects the ambivalence of English attitudes toward the Ottomans as described by many recent scholars, including Emily Bartels, Richmond Barbour, and Linda McJannet. Bartels notes that 'while the demonization of Oriental rulers provided a highly charged impetus for England's own attempts to dominate the East, their valorization provided a model for admiration and imitation, shaming or schooling the English into supremacy, or providing an excuse for defeat'. ${ }^{11}$ McJannet observes that the particular qualities for which early modern European historians 'admired the Ottomans' were 'unity, martial excellence, and strict justice, qualities which they sometimes felt were lacking in their own societies'. ${ }^{12}$

In addition to reproducing this larger societal ambivalence about the virtues and weaknesses of the Turks, the play raises questions about whether Turkishness inheres in their nature or in their society and laws. Although Amurath demonstrates strong passions for violence, his violent acts are also strongly motivated by social pressure. This pressure is initially embodied in Schahin, who tries to recall him to his former royal identity. Goffe also takes pains, however, to emphasize the power of social pressure throughout the play. Knolles reports that after decapitating Irene, Mahomet II 'meaning to discharge the rest of his choller, caused great preparation to be made for the conquest of PELOPONESVS, and the besieging of BELGRADE'. ${ }^{13}$ But in Goffe, Amurath asks his generals what his first act as a reinvigorated monarch should be; they shout in unison 'For Thracia!' (2.5.82), and he follows their lead.

As Amurath embarks on his military campaign, he seems to rouse his fury by conceiving it as an obligation: 'Our furie's patient! now will I be a Turke' 
(3.2.9). Although Amurath has just expressed a wish to wash his hands in Christian blood, he is apparently not as angry as he thinks he ought to be, and he encourages himself by invoking the stereotype of the stage Turk as an idealized Turkish identity to which he aspires. Similarly, when he is debating whether to stay with Eumorphe or to go out and conquer, he tries to shame himself by saying that 'The Christians now will scoffe at Mahomet; / Perchance they sent this wretch thus to inchant me!' (2.3.50-1). The exigencies of Turkish piety, then, are contrary not only to Christian piety but also, at least partially, to Amurath's own nature.

The final episode of the play crystallizes these conflicting narratives by presenting an exemplary instance of Turkish cruelty that seems divorced from violent passion. After Amurath's death, his son Baiazet ascends the throne and offers to share power with his younger brother Jacup. Schahin again intervenes, however, and tells Baiazet that to make himself and the realm secure, and to respect 'the Turkish Lawes' (5.4.143), he must kill his brother — in fact, that it would be unnatural to refrain from killing his brother. Eurenoses argues that the Turkish nation itself demands the murder of Jacup: 'Although we speake, yet thinke them not our words, / But what the Land speakes in us!' (5.4.177-8). Neither their arguments nor Baiazet's reluctant acquiescence displays the supposedly natural bloodthirstiness of the stereotypical Turk. Goffe's emphasis on the force of Turkish custom and precedent is a striking departure from Knolles, who identifies this episode as 'the beginning of the most vnnaturall and inhumane custome, euer since holden for a most wholesome and good policie amongst the Turkish kings and emperours'. ${ }^{14}$ What Knolles calls an effect of the killing, Goffe depicts as its cause.

Goffe's play thus raises questions about what kinds of savage behaviour are natural and what kinds are the result of social forces. Ultimately, it appears that the Turkish predilection for slaughter in this play is due less to volatile passions and more to the strictures of Turkish law and the imperative to emulate the idealized Turkish national type. Goffe thus shows the importance of socially constructed racial identities in determining behaviour and maintaining the imperial polity. Turkish law and honour require a self-denial that is conflated with Stoic virtue but that produces atrocious results. Despite its relative lack of psychological depth, the play offers a message that is arguably less racist than Shakespeare's Othello, where a Christian Moor who is fully acculturated to Western society nonetheless proves unable to restrain his natural passions. In contrast, Goffe emphasizes the ways in which social constraints direct supposedly natural behaviour. 
The play also suggests that this dynamic is not uniquely Turkish. In fact, it repeatedly gestures toward universalizing moral statements in which the Turks are merely stand-ins for humanity more generally. The conclusion of the play's verse argument presents Baiazet's fratricide as characteristic of politics, not of Turks: 'Thus still springs / The Tragick sport which Fortune makes with Kings' (23-4). Furthermore, Goffe's Turks are fairly invested in many aspects of Western culture and values: they are Petrarchan lovers and aficionados of neoclassical allusions and masques. Schahin uses Alexander the Great, also an admired figure in the West, as the mouthpiece for his views on Amurath's amorous behaviour, and he cites both universal natural examples and Roman precedent in arguing for Jacup's death (5.4.135-40). ${ }^{15}$ As noted earlier, Cobelitz shares warrior values with the Turks, and the Turkish forces appear at times to embody them better than Cobelitz's own people. Despite Amurath's savagery, his central position in the play and his love for the desirable Eumorphe facilitate audience identification with him. Conversely, audience sympathies aroused by Cobelitz's admirable piety and destruction of the Ottoman emperor are undercut by his position in the plot as the antagonist and by the manner of his killing of Amurath, which he achieves through treachery and concludes with somewhat unbecoming gloating and mockery.

Thus, the play makes it difficult for the audience to sustain a rigidly defined notion of 'us' and 'them'. Although Amurath's actions are stereotypically Turkish in their ultimate effects, his process of moral reasoning (and those of the other Turks) disorientingly yokes his Turk-like actions to Western ideologies such as Petrarchanism and Stoicism. Nonetheless, the Turkishness of Amurath and the other characters facilitates the play's commentary on issues that are not merely specific to Ottoman society. The Turks' reputation for strong, uncontrollable passions highlights the challenges of maintaining Stoic self-control and manifesting it in moral action, as when Amurath's effort to temper his amorous passions for Eumorphe leads to his intemperate passion for violence. Moreover, by associating the Stoic ideal with the inhuman strictures of an alien culture, the play dramatizes the difficulty of distinguishing between a lack of self-control (giving in to destructive, weak, or immoral passions) and excessive self-control (denial of sympathetic human passions). The play presents duty, passion, war, kingship, and love as potentially valuable, but ultimately Amurath's pursuit of these goals leads him to inhuman acts. The flexibility with which moral, especially Stoic, rationales are deployed makes it hard to tell whether there is a correct side in the love/ war debate. It suggests that Turks are driven by a complex mixture of passion, 
self-constraint, and social imperative. It calls into question the moral virtues espoused by both Christians and Turks, since they are used to rationalize things like neglecting one's governmental responsibilities, beheading one's beloved, and drinking the blood of Christians.

In this process, the ambiguity of the term 'Turk' serves as a pivot point between otherness and selfhood. As the play seems to use it, 'Turk' refers not only to a national identity in the world outside the theatre but also the stock character of English drama. In effect, The Courageous Turk treats the inhuman figure of the stage Turk as an actual cultural ideal to which the basically human Turkish characters aspire. This conflation of real and theatrical identities is supported by several instances of (admittedly clumsy) metatheatricality in the play, when characters compare themselves to actors (eg 2.2.15-17 and 5.4.99-102). Jacup highlights both the artificiality and the wickedness of this vision of Turkish identity by attributing his impending death to the decree of 'impious Statists': amoral, Machiavellian politicians (5.4.200). In contrast to Eurenoses, who claims that the land speaks through him (a naturalizing metaphor for Turkish identity), Jacup sees the conception of Turkish national values that demands his execution as a piece of propaganda cooked up for self-serving ends. Like Amurath, Jacup seems partially alienated from the supposedly natural Turkish identity.

The performative nature of Turkish identity has interesting implications for the English audience, who can see characters striving to conform to an ideal that may appear horrible or ridiculous to them. The epilogue concludes with a blatant appeal to the patriotic distinctions between Englishmen and Turks: 'All heer wish turkes destruction our hope stands / That to their ruine you'le all set your hands' (19-20). Nonetheless, to the extent that the universalizing impulses of the play itself repeatedly blur the distinction between the English self and the Ottoman other, The Courageous Turk may suggest the arbitrariness and constructed nature of England's own emerging sense of national identity, as well as the potentially monstrous consequences of enforcing conformity to that identity. 


\section{Notes}

1 William Shakespeare, The Complete Pelican Shakespeare, ed. Stephel Orgel and A.R. Braunmuller (New York, 2002).

2 Matthew Dimmock, New Turkes: Dramatizing Islam and the Ottomans in Early Modern England (Aldershot, 2005), 201.

3 Susan Gushee O'Malley (ed.), A Critical Old-Spelling Edition of Thomas Goffe's The Courageous Turk (New York, 1979), 36.

4 'wen: a lump or protuberance on the body' (Ibid, 2.4.39 n).

5 Richard Knolles, The Generall Historie of the Turkes from the first beginning of that nation to the rising of the Othoman familie (London, 1603; sтC: 15051), 350, 353.

6 Daniel J. Vitkus, Turning Turk: English Theater and the Multicultural Mediterranean, 1570-1630 (New York, 2003), 101.

7 Knolles, Generall Historie, 189.

8 Othello also displays ambivalence about self-restraint. Othello's inability to control his passions contributes to his downfall, but the play's most powerful articulation of the virtue of subordinating passion to reason comes from lago as part of his effort to corrupt Roderigo at the end of 1.3.

9 Knolles, Generall Historie, 353.

10 William Barksted, Hiren: or The faire Greeke (London, 1611; sTC: 1428), 97.2, 109.5, 114.1 .

11 Emily C. Bartels, 'The Double Vision of the East: Imperialist Self-Construction in Marlowe's Tamburlaine, Part One', Renaissance Drama 23 (1992), 5.

12 Linda McJannet, The Sultan Speaks: Dialogue in English Plays and Histories about the Ottoman Turks (New York, 2006), 60. The seemingly labile descriptions of the Turks in the early modern period (see also Richmond Barbour, Before Orientalism: London's Theatre of the East, 1576-1626 [Cambridge, 2003], 18) are so common that I suspect they represent, not the taste of an elite group of authors for ambiguity and paradox, but rather a typical early modern stance towards the other. These authors felt much freer than we might expect to praise peoples while in the same breath condemning them as savage.

13 Knolles, Generall Historie, 353.

14 Ibid, 201.

15 Su Fang Ng observes that 'a line of Ottoman sultans used Alexander the Great as an ideal model and expression of their claim to universal empire' and specifically cites Mehmed II as 'An avid reader of Homer and the Life of Alexander' ('Global 
Renaissance: Alexander the Great and Early Modern Classicism from the British Isles to the Malay Archipelago', Comparative Literature 58 [2006], 297).

\section{'By Mortus Ali and our Persian gods': Multiple Persian Identities in Tamburlaine and The Travels of the Three English Brothers}

'Before a study of the impact of Persian and Mughal Muslims on Renaissance England is conducted - a project that has yet to be undertaken - an investigation of the impact of the Turks and Moors of the Ottoman Empire and North Africa must be completed'. ${ }^{1}$ In the same year that Nabil Matar made this statement and championed the study of early modern AngloIslamic interaction and literary reception in the so-called 'Turkish plays', Linda McJannet insisted on '[b] ringing ... a Persian' into the scene. ${ }^{2}$ Inspired by Parr's long-overdue edition of The Travels of the Three English Brothers, ${ }^{3}$ McJannet's article surveyed the bulk of writings on matters Persian in relation to Renaissance drama. Her discussion of Robert Baron's closet drama Mirza in particular drew attention to the multiple discourses of Persia (Islamic and otherwise) embedded in the text. ${ }^{4}$ In what follows I attempt to endorse an awareness of multiple Islamic identities in this era against another exclusivist yet prevailing trend that at the cost of marginalization of distinct historical identities settles 'on the designation "Turkish" plays ... as it was used in the early modern period, to signify all Muslim peoples' including 'Arabs, Moroccans, Persians, Indians, and the Muslim peoples of South East Asia'. 5 In fact, as I shall argue, no study of individual Islamic identities and their impact on early modern English theatre is satisfactory or complete without an awareness of the interrelations between those identities and the complexities that such interrelations would create for a London audience familiar with diversified modes of religious discourse.

Although recent scholarship affirms that 'English representations of Islam were complex and nuanced' and far from 'simplification and stereotyping' commonly believed since Chew's study, ${ }^{6}$ there is a critical tendency to overlook such diversity. This reductive approach is often based on two grounds: first, that "Islam, and "Turkishness" were often considered synonymous in early modern parlance'; 7 second, that 'the plays' understanding of Islam is meditated by England's commercial and political connections with the Ottoman Empire', especially trade via the Levant route. ${ }^{8}$ The doctrinal implications of 